\title{
Türkiye Yükseköğretim Sisteminde Eğitimin Getirileri: Ampirik Bir Uygulama'
}

\author{
Yüksel YEŞiLBAĞ*
}

\begin{abstract}
Öz: Bu araştırma üniversite de çeşitli bölümlerde yapılan sosyal ve bireysel eğitim yatırımlarının getiri oranlarını hesaplamayı amaçlamaktadır. Araştırmada tarama modeli kullanılmıştır. Çalışma gurubunu, on beş farklı yükseköğretim bölümünden mezun olup İstanbul' da özel sektörde ücretli olarak çalışan 795 kişi oluşturmaktadır. Maliyetlere ilişkin veriler YÖK'ün 1997 yılında yaptığı araştırmadan, kazançlara ilişkin verilerse araştırmacı tarafından geliştirilen anket aracılığıyla elde edilmiştir. Araştırmada sosyal ve bireysel getiriler kısa-yol yöntemiyle hesaplanmıştır. Ayrıca maliyet-fayda analizinde kullanılan yöntemlerden olan fayda-maliyet oranı ile üniversite yatırımının sosyal ve bireysel açıdan verimliliği test edilmiştir. Araştırmada şu bulgulara ulaşılmıştır: Tüm bölümlerde sosyal getiri oranları $\% 5$ - $\% 14,8$; bireysel getiriler $\% 12,3$ $\% 18,5$ arasında değişmektedir. Üniversite eğitiminin sosyal getiri oranı $\% 8,9$, fayda-maliyet oranı 11,93; bireysel getiri oranı $\% 16,6$, fayda-maliyet oranı 15,17' dir. Cinsiyetler açısından anlamlı farklılık görülmemiştir. Bireysel getiri oranı kadınlar için $\% 16,3$, erkekler için \%16,6 bulunmuştur. Bu hesaplamalar tüm Türkiye çapında ve bütün eğitim tür ve düzeylerinde daha geniş bir örneklem üzerinde yapılmalıdır.
\end{abstract}

Anahtar Sözcükler: Eğitimin Getirileri, Eğitimde Maliyet Fayda Analizi, Yükseköğretimin Getirileri

\section{Returns to Education at the System of Turkish Higher Education: An Ampirical Study}

\begin{abstract}
This research aims to estimate the rates of return to higher education. Survey method was used. The data gathered from 795 people graduated from higher education and worked as wage earners at private sector in Istanbul. The data related to costs were obtained from the findings of the research done previously by YOK, the data on earnings were gotten from wage earners by a questionnaire developed by the researcher. The social and private rate of returns were estimated using short-cut method. Social and private productivity of the investments were tested by benefit-cost ratio. The following findings were reached: the social rates of return vary from $\% 5$ and $\% 14,8$ and private rates of return vary from $\% 12,3$ and $\% 18,5$. The social rate of return is $\% 8,9$, benefit-cost ratio is 11,93 and the private rate of return is $\% 16,6$, benefit-cost ratio is $\% 15,17$. The research does not reveal a significant difference between genders. The private rate of return is $\% 16,3$ for women and $\% 16,6$ for men.
\end{abstract}

Keywords: Return to Education, Cost Benefit Analysis in Education, Return to Higher Education 
Eğitim hem toplumsal hem de bireysel gelişmeye katkı sağlayan temel bir unsurdur. Özellikle bir toplumun sosyal, kültürel, ekonomik, teknolojik vb. yönlerden gelişebilmesi için önemli bir etkendir. Bu durum eğitimin işlevlerine bakıldığında görülmektedir. Büyük gelişmeler sağlamak isteyen devletler eğitime daha fazla kaynak ayırarak piyasanın insan gücü ihtiyaçları doğrultusunda her bir bireyin en yüksek noktaya kadar eğitim görmelerini sağlamak zorundadırlar. Ancak bunun için gerekli altyapıyı (insan kaynakları, binalar, araç-gereçler, vb.) hazırlayabilmek büyük yatırımlar anlamına gelmektedir. Bununla birlikte hükümetler kaynakların etkin biçimde dağıtılması konusunda her zaman yeterince başarılı değillerdir.

Eğitimin bir maliyeti vardır. Kamu ya da birey, elindeki kaynağın belli bir bölümünü harcama yapması gereken diğer bazı alanlardan vazgeçerek ya da bu alanlardan fedakârlıkta bulunarak eğitime ayırmaktadır. Doğal olarak yapılan bu kaynak ayırımı, ayıran açısından bir maliyet demektir. Bu durumda kaynakların eğitim düzeyleri arasında nasıl dağıtılacağını belirlemek ciddî çalışmaları gerektirmektedir. Kuşkusuz kaynak ayırma kamu açısından zor fakat gerçekleştirilebilir bir durumdur. Etkili ve etkin bir şekilde yapılamadığında, örneğin makro düzeyde Gayri Safî Milli Hâsıladan eğitime ayrılan pay düşürüldüğünde eğitimin birçok alanında nitelik düşüşü söz konusu olacaktır. Daha açık deyişle yetersiz binalarda, eğitim araç-gereçlerinden yoksun sınıflarda, gerekli öğretmenlik ve yöneticilik formasyonuna sahip olmayan öğretmen ve yöneticilerle eğitimin niteliğini beklenen ya da istenen düzeye yükseltmek pek mümkün görünmemektedir.

Özellikle 1950'li yıllardan sonra eğitim ve ekonomi ilişkisi üzerine yapılan araştırmalarda, eğitimin birey ve toplum için ekonomik kazanç sağladığı, toplumda verimliliği artırdığı, ülkenin ekonomik refah düzeyine katkıda bulunduğu, yani ekonomik bir değerinin olduğu sonuçlarına ulaşılmıştır. Dolayısıyla eğitime yapılan harcamaların karşılığının mutlaka hem toplum hem de birey tarafından alındığı söylenebilir. Ancak bu noktada şu sorular akla gelmektedir: Eğitime yapılan harcamalar yatırım mıdır tüketim midir? İnsan sermayesine yapılan harcamalar mı ekonomik gelişmeye daha büyük katkıda bulunur yoksa fizikî sermayeye yapılan harcamalar mı? Kamu ve birey için eğitimin bütün türleri ve düzeyleri aynı derecede verimli midir? Eğitim yatırımının, toplum için olduğu kadar birey için de getirisi var mıdır? Eğitim, bireysel getirisi olan bir yatırımsa bireyler eğitim ve meslek seçiminde bu noktayı dikkate almakta mıdırlar?

Yükseköğretim özelinde ise bu eğitim düzeyinin maliyetinin üstlenilmesi konusunda birçok soru ortaya çıkmaktadır. Öğrenci katkısı, üniversiteye gitmenin fırsat maliyeti, harcanan para ve zaman, bu eğitim düzeyine yatırımın değerini mi göstermektedir? Özellikle düşük gelirli ailelerde bu tür bir yatırım kararı almak gerçekten çok zordur. Türkiye' de iş olanakları görece düşük bir hızla artmaktayken, işgücü piyasasına giren üniversite mezunlarının arzında ortaya çıan önemli orandaki artışın piyasadaki iş rekabetini artırması da böyle bir yatırıma karar vermeyi zorlaştırmaktadır. Bu nedenle eğer bir insan sermayesi yatırımı olduğu düşünülüyorsa yükseköğretimin gerçekten değerli bir yatırım olup olmadığı, bu yatırımın sosyal ve bireysel getiri oranları özenle incelenmelidir.

\section{Problem}

Bu araştırmanın problemi, Türkiye' de üniversite giriş sınavında en çok tercih edilen 15 bölüme kamunun ve tek tek bireylerin yaptığı toplam harcamalar ile bu harcamaların sosyal ve bireysel getiri oranlarının belirlenmesidir.

\section{Amaç}

Bireylerin, ilk sırada tercih ettikleri bölümleri ekonomik getirilerinin daha yüksek olduğunu düşündükleri için üniversiteye giriş sınavında bunları birinci sırada tercih ettikleri varsayılmaktadır. Kuşkusuz kuramsal olarak bu tercihlerin toplumda daha iyi bir statü, daha iyi bir meslek edinmek gibi nedenlerle yapıldığı da söylenebilir. Bununla birlikte daha iyi bir statü ve daha iyi bir mesleğin ekonomik getirilerinin büyük olacağ 1 varsayımıyla bu çalışmada tercihlerin büyük oranda ekonomik getirileri nedeniyle yapıldığı kabul edilmektedir. Makro açıdan ise seçilen yükseköğretim bölümlerinin, kamunun daha fazla fayda beklediği bölümler olduğu söylenebilir. Buna göre yapılan bu araştırmanın temel amacı yükseköğretim düzeyinde belirli bölümlerde yapılan sosyal ve bireysel yatırımların getirilerinin belirlenmesidir. Bu amaç doğrultusunda şu sorulara cevap aranmaktadır:

1. Katılımcılar kişisel ve demografik özellikleri bakımından nasıl bir dağılım göstermektedir? 
2. Belirlenen 15 üniversite bölümüne yapılan toplam kamusal harcamaya karşlık bu bölümlerin sosyal getirileri nasıldır?

3. Katılımcıların lisans eğitimleri boyunca yaptıkları kişisel harcamalara karşılık mezuniyet sonrası elde ettikleri kazançların düzeyi nasıldır?

4. Tüm bölümler genelinde üniversite eğitiminin sosyal ve bireysel getirileri nelerdir?

5. Hem sosyal hem de bireysel getiriler cinsiyete göre anlamlı bir farklılık göstermekte midir?

\section{Önem}

Genelde üniversitenin, özelde ise üniversite düzeyinde bazı dallara yapılan sosyal ve bireysel harcamaların, elde edilen getirilerle karşılaştırıldığında, üstlenilmesinin ekonomik açıdan rasyonel olup olmadığının belirlenmesi konusu, kaynakların nasıl ayrılacağı noktasında büyük önem taşımaktadır. Kamunun, mevcut kaynaklarının ne kadarını yükseköğretime ve/ya da belirli bölümlerine ayırması ve bireyin bir üniversite eğitimi alıp almamasına karar vermesi bir takım değerlendirme ölçütlerine göre yapılmaktadır. $\mathrm{Bu}$ ölçütlerden biri de getiri oranı hesaplamasıdır. Buna göre yapılan bu çalışmanın bulgularının, Türkiye'de özellikle makro düzeyde kıt kaynakların eğitimin farklı tür ve düzeyleri arasında etkin dağıtımı konusunda eğitim politikalarına bir rehber olması ve öğrencilerin en azından parasal faydaları nedeniyle liseden sonra üniversiteye devam edip etmeyeceklerine karar vermelerinde önemli bir kanıt olması beklenmektedir. Ayrıca yükseköğretimin hem sosyal hem de bireysel getirilerinin ortaya çıkarılmasının yükseköğretimin finansmanı konusunda da yeni ve farklı politikaların uygulanmasında önemli bir literatür niteliği görmesi umulmaktadır.

\section{Varsayımlar}

Bu araştırmanın varsayımları şunlardır:

1. Bu çalışmada incelenen bireylerin, üniversite sınavında tercih ettikleri bölümleri, mezun olduktan sonraki getirilerini düşünerek seçtikleri varsayılmaktadır.

2. Üniversite ve lise mezunları arasındaki mutlak kazanç farkının tamamı üniversite eğitimine atfedilmektedir.

3. Lise mezunlarının, Devlet Memurları Kanunu'na göre 13. derecenin 1. kademesinde çalışan bir lise mezununa ödenmek üzere 2005 yılı ocak ayında belirlenen ücreti eğitim süresi boyunca (tıp fakültesi hariç 4 yıl) aldıkları kabul edilmiştir.

4. Araştırma kapsamında yalnızca İstanbul'da özel sektörde ücretli olarak çalışıp veri toplama aracını dolduranların, kendileriyle ilgili bilgileri doğru biçimde yansıttıkları varsayılmaktadır.

\section{Sinırlılıklar}

$\mathrm{Bu}$ araştırmanın sınırlılıkları şunlardır:

1. Araştırma yalnızca yukarıda belirlenen 15 bölümle ilgili sosyal ve bireysel getiri oranları ile faydamaliyet oranının hesaplanmasıyla sinırlı tutulmuştur.

2. Araştırmada kullanılan kazançlarla ilgili veriler 2005 yılının şubat ayındaki verilerle sınırlıdır.

3. Araştırma yalnızca İstanbul'da özel sektörde çalışan belirlenmiş meslek uzmanlarının görüşleriyle sinırlıdır.

4. Özel sektörde çalışanlar kategorisinde ücretliler incelenmiş, karşılaştırılabilir kazanç ölçütlerine ulaşma zorlukları nedeniyle kendi hesabına çalışanlar ile yönetici konumunda olanlar ele alınmamıştır.

5. Çalışanların saat ücretleri gözlenemediği için hesaplamalarda yalnızca ücretlilerin aylık kazançları alınmıştır.

\section{Yöntem}

\section{Araştırmanın Modeli}

Araştırmada belirlenmiş 15 yükseköğretim bölümüne yapılan kamusal ve bireysel yatırımlar ile bu yatırımların getirilerinin olduğu gibi ortaya çıarılması amaçlandığı için genel tarama modeli kullanılmıştır. Çünkü tarama modeli, geçmişte ya da günümüzde var olan bir durumu, var olan biçimiyle betimlemeyi amaçlamaktadır (Karasar, 2014). 


\section{Evren ve Örneklem}

Araştırmanın çalışma grubunu belirtilen 15 bölümden mezun olduktan sonra İstanbul il merkezinde küçük ya da büyük ölçekli bir özel kurumda ücretli olarak çalışan 340'1 $(\% 42,8)$ kadın, 455'i $(\% 57,2)$ erkek olmak üzere 795 birey oluşturmaktadır. Örneklem büyüklüğü Yazıcıŏ̆lu ve Erdoğan (2004) tarafından ideal örneklem büyüklügünün $\% 97$ güven aralığı ve \%0,03 hata payılla evrenin 1 milyon ve üstü olması durumunda örneklemin en az 682 kişi olarak gösterildiği çalışmasından yola çıkılarak seçilmiştir. Doldurulan 807 anket iç tutarlıklarına göre elenmiş, araştırma kapsamında olmayan 12 tanesi çıkarılmıştır. Sonuç olarak 795 katılımcının anketi geçerli olarak hesaplamalara dahil edilmiştir. Her bir bölümden mezun ortalama 53 kişinin bu anketi doldurduğu görülmüştür. Çalıştığı işyerinde yönetici konumda olanlar, kendi hesabına çalışanlar ve kamu personeli kapsam dişında tutulmuştur.

Katılımcıların cinsiyete ve mezun oldukları bölümlere göre dağılımları Tablo 1'de yer almaktadır.

Tablo I

Katılımcıların Cinsiyete ve Mezun Oldukları Bölüme Göre Dağıllmları

\begin{tabular}{|c|c|c|c|c|}
\hline \multirow[t]{2}{*}{ Mezun Olunan Bölüm } & \multicolumn{3}{|c|}{$\mathrm{f}$} & \multirow{2}{*}{$\begin{array}{c}\% \\
\text { Genel Toplam }\end{array}$} \\
\hline & Kadın & Erkek & $\mathrm{T}$ & \\
\hline Öğretmenlik-Eğitim Bilimleri & 29 & 34 & 63 & 7,9 \\
\hline Tip & 23 & 41 & 64 & 8,1 \\
\hline Hukuk & 22 & 39 & 61 & 7,7 \\
\hline İşletme & 33 & 24 & 57 & 7,2 \\
\hline Elektrik-Elektronik Mühendisliği & 13 & 34 & 47 & 5,9 \\
\hline Uluslararası İlişkiler & 17 & 21 & 38 & 4,8 \\
\hline Bilgisayar Mühendisliği & 16 & 23 & 39 & 4,9 \\
\hline Endüstri Mühendisliği & 28 & 31 & 59 & 7,4 \\
\hline İnşaat Mühendisliği & 14 & 61 & 75 & 9,4 \\
\hline Makine Mühendisliği & 14 & 30 & 44 & 5,5 \\
\hline İktisat & 30 & 36 & 66 & 8,3 \\
\hline Mimarlık & 29 & 23 & 52 & 6,5 \\
\hline Mütercim-Tercümanlık & 26 & 16 & 42 & 5,3 \\
\hline Matematik & 19 & 24 & 43 & 5,4 \\
\hline Müzik Eğitimi & 27 & 18 & 45 & 5,7 \\
\hline Toplam & 340 & 455 & 795 & 100 \\
\hline
\end{tabular}

Araştırmada en fazla inşaat mühendisliği, iktisat, tıp, öğretmenlik ve hukuk bölümlerinden mezunlara ulaşılabilmiştir. Araştırmanın özel sektörde yönetici konumda olmayan ücretli çalışanlarla sınırlı olması nedeniyle uluslararası ilişkiler, bilgisayar mühendisliği, mütercim-tercümanlık gibi bazı bölümlerde çok fazla mezuna ulaşılamamıştır. Ancak ulaşılabilen sayının istatistiksel hesaplamalar için yeterli olduğu kabul edilmektedir.

Yaş grubuna ilişkin verileri Tablo 2' de gösterilmektedir.

Tablo II

Katılımcıların Yaş Grubuna Göre Dă̆gllımları

\begin{tabular}{lcc}
\hline Yaş Grubu & f & $\mathbf{\%}$ \\
\hline 24 ve altı & 116 & 14,6 \\
\hline $25-34$ & 374 & 47,1 \\
\hline $35-44$ & 195 & 24,5 \\
\hline $45-54$ & 77 & 9,7 \\
\hline $55-64$ & 33 & 4,1 \\
\hline 65 ve üstü & - & - \\
\hline Toplam & $\mathbf{7 9 5}$ & $\mathbf{1 0 0}$ \\
\hline
\end{tabular}

Katılımcıların \%14,6'sının (116 kişi) 24 ve altı; \%47,1'inin (374 kişi) 25-34; \%24,5'inin (195 kişi) 35-44; \%9,7'sinin (77 kişi) 45-54 ve \%4,1'inin (55-64) yaş grubunda oldukları görülmektedir. 65 ve üstü yaş grubunda hiç denek yoktur.

Katılımcıların meslekteki hizmet süresine göre dağılımları Tablo 3’te görüldüğ̈̈ gibidir. 
Tablo III

Katılımclların Meslekteki Hizmet Süresine Göre Dağılımları

\begin{tabular}{lcc}
\hline Meslekteki Hizmet Süresi & f & \% \\
\hline $1-10$ & 490 & 61,6 \\
\hline $11-20$ & 196 & 24,7 \\
\hline $21-30$ & 76 & 9,6 \\
\hline $31-40$ & 33 & 4,1 \\
\hline 41 ve üstü & - & - \\
\hline Toplam & $\mathbf{7 9 5}$ & $\mathbf{1 0 0}$ \\
\hline
\end{tabular}

Katılımcıların \%61,6'sı (490 kişi) 1-10 yıl; \%24,7'si (196 kişi) 11-20 yıl; \%9,6'sı 21-30 yıl ve \%4,1'i 31-40 yıl hizmet süresine sahiptir.

\section{Verilerin Toplanması ve Yorumlanması}

Araştırmada demografik ve kazanç verilerini toplamak için kullanılan veri toplama aracı, uzman görüşlerine başvurularak 29 soru halinde araştırmacı tarafından hazırlanmış ve araştırma kapsamına girip özel sektörde çalışan bireylere uygulanmıştır. Yükseköğretime girişte ilk sırada tercih edilen bölümlerin istatistikleri ve bireysel maliyetlere ilişkin veriler ise 1990-2010 yılları arasında Yüksek Öğretim Kurumu [YÖK] (1997) tarafından ilk ve tek defa 1997 yılının mayıs ve haziran aylarında 80.000 öğrenci üzerinde yapılan bir araştırmadan toplanmıştır. YÖK'ün araştırması dışında bu konuda yapılan başka bir çalışma bulunmamaktadır. Bu nedenle araştırma sonucunda ortaya çıkan ilk tercih edilen on beş bölüm aynen alınmıştır (Tablo 4).

Araştırmanın amaçlarında ifade edilen ve özel sektörde çalışan meslek gruplarındaki kişilere değişik meslek odalarının Türk Mühendis ve Mimar Odaları Birliği [TMMOB]'a bağlı odalar, İstanbul Tabip Odası gibi) yardımlarıyla ve bireysel çabalarla ulaşılmıştır. Veri toplama aracı, bu kişilere ya elden verilmiş ya da eposta yoluyla gönderilmiştir. Bunun dışında bir web tasarımcısı tarafından "asp" formatında hazırlanmış olan anket http://www.alifuat.com/anket sayfasına konulmuş ve çalışma evreninde yer alıp e-posta adresi olanlara bu web sayfası bir link olarak gönderilmiştir. Bu şekilde doldurulan anketler doğrudan araştırmacının veri tabanında saklanmıştır.

Tablo IV

1997 Yılında Üniversite Giriş Sınavında Öğrencilerin Ilk Tercih Ettikleri Bölümler

\begin{tabular}{lc}
\hline Bölüm & Yüzde \\
\hline Öğretmenlik-Ĕ̆itim Bilimleri & 14,0 \\
\hline Tıp & 13,9 \\
\hline Hukuk & 12,8 \\
\hline İletme & 7,7 \\
\hline Elektrik-Elektronik Mühendisliği & 6,7 \\
\hline Uluslararası İlişkiler & 5,6 \\
\hline Bilgisayar Mühendisliği & 5,5 \\
\hline Endüstri Mühendisliği & 4,3 \\
\hline İnşaat Mühendisliği & 3,1 \\
\hline Makine Mühendisliği & 2,7 \\
\hline İktisat & 2,2 \\
\hline Mimarlik & 2,7 \\
\hline Mütercim-Tercümanlı & 1,8 \\
\hline Matematik & 1,7 \\
\hline Müzik Ĕ̈itimi & 0,6 \\
\hline
\end{tabular}

Araştırmada kullanılacak diğer veriler; çeşitli kütüphanelerden, kurumlardan ve internetten elde edilmiştir. Buna göre maliyet, gelir, öğrenci sayıları, eğitim harcamaları ve istihdam ile ilgili veriler için Millî Eğitim Bakanlığı, Maliyet Bakanlığı, Devlet İstatistik Enstitüsü, Devlet Plânlama Teşkilatı, Yükseköğretim Kurulu, Ekonomik Kalkınma ve İşbirliği Teşkilatı ve Dünya Bankası kaynaklarından yararlanılarak elde edilmiştir.

Araştırmada doğrudan bireysel maliyetler olarak YÖK'ün 1997 yılında yaptığı araştırma bulguları esas alınmıştır. Bu araştırmada 1997 yılının bahar döneminde bir öğrencinin ortalama aylık okul harcaması 257,28 
TL olarak çıkmıştır². Bir öğretim yılının 9 ay ve normal eğitim süresinin (tıp fakültesi hariç) 4 yıl olduğu düşünüldügünde 4 yıllık bir lisans programından mezun olan bir öğrencinin 4 yıllık doğrudan harcamaları toplamı 9x257,28x4 (eğitim süresi) $=9.262,08$ ve bir tıp fakültesi öğrencisinin 6 yıllık doğrudan harcamaları toplamı 9x257,28x6 (eğitim süresi) = 13.893,12 lira olarak alınmıştır.

YÖK (1997) sonuçlarına göre öğrencilerin harcama kalemlerinin kişisel harcamalar içindeki payları ise Tablo 5'teki gibidir.

Tablo V

Öğrencilerin Harcama Kalemlerinin Kişisel Harcamalar İçindeki Payları

\begin{tabular}{lc}
\hline Harcama Kalemi & Yüzde \\
\hline Beslenme & 26 \\
\hline Barınma & 15 \\
\hline Ulaşım & 14 \\
\hline Giyim & 12 \\
\hline Ders Kitapları & 12 \\
\hline Katkı Payı & 11 \\
\hline Kültürel ve Sosyal Etkinlikler & 10 \\
\hline
\end{tabular}

Öğrenci başına birim maliyetler alınırken üniversite ve üniversitenin bulunduğu il/coğrafî bölge ayrımı yapılmamıştır. Bunun yerine bölümlerin ağılıklı ortalamaları alınmıştır. Dolaylı bireysel maliyetler, yani vazgeçilen kazançlar için de Ocak 2005 yılından itibaren geçerli olmak üzere 13. derecenin 1. kademesindeki lise mezunu bir devlet memuru için belirlenen net 525,76 YTL, sosyal maliyet hesaplamasında ise brüt 839,60 YTL ölçüt kabul edilmiştir.

Örneklem grubunda yer alan üniversite mezunlarının kazançları belirtilen anket aracılığıyla toplanmıştır. Bireylerin elde ettikleri kazançlar 12 ayrı seçenek olarak gösterilmiştir. Bu seçeneklerden birincisi olan 1-499 YTL aralığı için ortalama kazançlar daha çok üst sınıra yakın olduğu düşünülerek 450 YTL olarak alınmıştır. İstatistiksel açıdan daha uygun olduğu için geri kalan tüm aralıkların orta değerleri kabul edilmiştir. Örneğin 500-999 aralığı için 750; 1.000-1.499 aralığı için 1.250; 1.500-1999 aralığı için 1.750 YTL; 2000-2.499 aralığı için 2.250 YTL gibi.

Çalışmada, eğitimin sosyal ve bireysel getirileri kısa-yol formülü ile hesaplanmıştır. Bununla birlikte genel olarak sosyal ve bireysel fayda-maliyet oranı hesaplaması yapılmıştır. Eğitimin sosyal getirileri hesaplanırken vergi-öncesi gelir rakamları, bireysel getirileri hesaplanırken vergi sonrası gelirler kullanılmıştır.

\begin{tabular}{|c|c|c|}
\hline Sosyal getiri oranı & $r=$ & $\frac{\bar{E}_{u}-\bar{E}_{S}}{4\left(\bar{E}_{S}+C_{u}\right)}$ \\
\hline Bireysel getiri oranı & $r=$ & $\frac{\bar{E}_{u}-\bar{E}_{s}}{4\left(\overline{E_{u}}\right)}$ \\
\hline Sosyal fayda-maliyet oranı & & $\frac{\bar{E}_{u}-\bar{E}_{S}}{C_{u}}$ \\
\hline Bireysel fayda-maliyet oranı & & $\frac{\bar{E}_{u}-\bar{E}_{S}}{C_{u}}$ \\
\hline
\end{tabular}

Türkiye'de üniversite mezunu çalışanların üniversite eğitiminden kaynaklanan 43 yıllık ${ }^{3}$ ek kazançları ile üniversite eğitimi almak için yaptıkları harcamalara ilişkin çapraz-kesit yöntemi ile tahminde bulunmanın yanıltıcı sonuçlar ortaya çıkaracağı endişesi ile net bugünkü değer hesaplaması yapılmamıştır. 43 yıllık bir dönem Türkiye açısından ekonomik ve sosyal değişimler için çok uzun bir süre olduğundan, net bugünkü değer hesaplamasında da bir faiz oranının kullanılması gerektiğinden Türkiye'de eğitim yatırımları sonucunda oluşacak ek yaşam boyu gelirin net bugünkü değerini hesaplamanın çok sağlam sonuçlar vermeyeceği düşünülebilir.

Verilerin analizi ve yorumları yapıldıktan sonra elde edilen bulgular Türkiye'de ve Dünya'da yapılan

\footnotetext{
22005 yılında yeni Türk lirasına (YTL) geçildiği için bu çalışmada kullanılan tüm parasal değerler YTL cinsinden ele alınmaktadır.

${ }^{3}$ İşgücü arzı Türkiye'de 15-65 yaş arasındaki nüfusu kapsamaktadır. 7 yaşında ilkokula başlayan birinin sinıf tekrar yapmadığında 22 yaşında üniversiteden mezun olması ve mezun olur olmaz birincil işgücü piyasasında çalışmaya başlaması durumunda çalışma yaşamı maksimum 65 yaşında bitecektir. İş yaşamında gelir elde edeceği süre bu nedenle 43 yıl olarak belirtilmiştir.
} 
diğer çalışmalarla karşılaştırılmıştır. Üniversite eğitimi almanın bireye ya da topluma sağladığı parasal olmayan faydalar ve maliyetler dikkate alınmamıştır. Çalışanların kazançlarını etkileyebilecek kayırma, zekâ, doğal yetenek, okul sonrası alınan kurslar ve eğitimin kalitesindeki farklılıkların etkileri veri sınırlılıkları nedeniyle hesaba katılmamıştır.

\section{Bulgular}

Araştırmada elde edilen bulgular araştırma amacına uygun biçimde aşağıdaki başlıklar altında toplanarak açıklanmış ve yorumlanmıştır.

\section{Kamunun Belirlenmiş Üniversite Bölümlerine Yaptığı Toplam Harcamalar ile Getirilere İlişkin Bulgular}

Yükseköğretimde birim maliyet hesaplanırken aritmetik ortalamalara göre elde edilmiş verilerin yanıltıcı olacağı düşünülmektedir. Çünkü eğitimin türü ve alanlarına göre birim maliyetler önemli farklılıklar göstermektedir. Örneğin Tablo 6' da görüldüğü gibi 2004 yılında tıp fakültesinde ve konservatuvarda eğitim gören bir öğrencinin hem kamuya hem de ailesine maliyeti iletişim, eğitim bilimleri, hukuk, iktisat, işletme bölümlerinde eğitim gören bir öğrencinin maliyetinden yüksektir. Bu farklılıklar hem eğitim sürelerinin değişmesinden hem de eğitimde kullanılan farklı teknolojiden kaynaklanabilir. Kamu bütçesinden yapılan harcamalar, eğitim alanlarına göre fakülte ve yüksekokul bazına kadar ayrıntıyla gösterilebilmektedir. Bu nedenle bu çalışmada birim harcamalar fakülte bazında ele alınmıştır. Hesaplamalar açısından kolaylık olması nedeniyle 2005 öncesi rakamlar YTL'ye çevrilmiştir.

Sosyal getiri oranlarının hesaplanabilmesi için öncelikle maliyetle ilgili verilerin bilinmesi gerekmektedir. Her bir bölüme ayrılan kaynak miktarının o bölümdeki öğrenci sayısına bölünerek ortaya çıkarılan öğrenci başına birim maliyetler YÖK (2004) tarafından yayınlandığı için tekrar böyle bir hesaplama yapılmamıştır. Bununla birlikte sosyal maliyetler Tablo 6'da görüldüğü gibi hesaplanmıştır.

Tablo VI

Bölümlere Göre Öğrenci Başına Birim Maliyetler, Sosyal Maliyetler ve Aylık Ortalama Kazançlar

\begin{tabular}{|c|c|c|c|c|c|}
\hline Bölümler & $\begin{array}{l}2004 \text { Yilında } \\
\text { Yillık Birim } \\
\text { Maliyetler }\end{array}$ & $\begin{array}{c}\text { Toplam } \\
\begin{array}{c}\text { Doğrudan Sosyal } \\
\text { Maliyetler }\end{array} \\
\end{array}$ & $\begin{array}{c}\text { Dolaylı Sosyal } \\
\text { Maliyetler }\end{array}$ & $\begin{array}{c}\text { Toplam } \\
\text { Yillık Sosyal } \\
\text { Maliyetler } \\
\end{array}$ & $\begin{array}{l}\text { Aylık Ortalama } \\
\text { Kazançlar }\end{array}$ \\
\hline Öğretmenlik-Eğitim Bilimleri & $1.305,00$ & 5.220 & $40.300,08$ & $13.695,72$ & $1.440,00$ \\
\hline Tip & $9.882,00$ & 59.292 & $60.451,20$ & $22.272,72$ & $2.034,00$ \\
\hline Hukuk & $1.467,00$ & 5.868 & $40.300,08$ & $13.857,72$ & $1.445,00$ \\
\hline İşletme & $1.467,00$ & 5.868 & $40.300,08$ & $13.857,72$ & $1.243,00$ \\
\hline Elektrik-Elektronik Mühendisliği & $1.944,00$ & 7.776 & $40.300,08$ & $14.334,72$ & $1.632,00$ \\
\hline Uluslararası İlişkiler & $1.467,00$ & 5.868 & $40.300,08$ & $13.857,72$ & $1.630,00$ \\
\hline Bilgisayar Mühendisliği & $1.944,00$ & 7.776 & $40.300,08$ & $14.334,72$ & $1.532,00$ \\
\hline Endüstri Mühendisliği & $1.944,00$ & 7.776 & $40.300,08$ & $14.334,72$ & $1.470,00$ \\
\hline İnşaat Mühendisliği & $1.944,00$ & 7.776 & $40.300,08$ & $14.334,72$ & $1.953,00$ \\
\hline Makine Mühendisliği & $1.944,00$ & 7.776 & $40.300,08$ & $14.334,72$ & $2.043,00$ \\
\hline İktisat & $1.467,00$ & 5.868 & $40.300,08$ & $13.857,72$ & $1.430,00$ \\
\hline Mimarllk & $1.944,00$ & 7.776 & $40.300,08$ & $14.334,72$ & $1.606,00$ \\
\hline Mütercim-Tercümanlık & $1.625,00$ & 6.500 & $40.300,08$ & $14.015,72$ & $1.477,00$ \\
\hline Matematik & $1.625,00$ & 6.500 & $40.300,08$ & $14.015,72$ & $1.413,00$ \\
\hline Müzik & $1.305,00$ & 5.220 & $40.300,08$ & $13.695,72$ & $1.261,00$ \\
\hline Toplam (Ortalama) & $2.218,26$ & $10.190,66$ & $41.643,48$ & $14.608,98$ & $1.573,93$ \\
\hline
\end{tabular}

Kaynak: YÖK, 2004: 127.

Eğitimin doğrudan sosyal maliyetleri hesaplanırken kamu tarafından öğrenci başına yapılan birim harcamalar eğitim süresi ile çarpılmıştır. Dolaylı sosyal maliyetler ise $13^{\prime}$ üncü derecenin 1 . kademesinde çalışan lise mezunu bir devlet memuru için belirlenen aylık brüt ücretin (839,60 YTL) bir yıllık toplamının eğitim süresi ile çarpılmasıyla bulunmuştur. Yıllık toplam sosyal maliyet ise doğrudan ve dolaylı maliyetler ile doğrudan bireysel maliyetin toplamıdır. Görüldüğü gibi en büyük maliyetler tıp fakültesindedir. Öğrenci başına birim maliyetin aynı olduğu bölümlerde maliyetler eğitim süresi dört yıl olduğu için doğal olarak aynıdır. Yalnızca Tablo 6'daki verilere göre getiri oranı hesaplanamamaktadır. Bireyin yaptığı hem doğrudan hem de dolaylı maliyetler ile aldığı kazancın da bilinmesi gerekmektedir. Tablo 7'de bunlara ilişkin 
veriler yer almaktadır. Bu verilerden hareketle ilgili bölümlere yapılan kamusal yatırımların sosyal getiri oranı aşağıdaki gibi hesaplanabilir.

\begin{tabular}{|c|c|c|}
\hline Öğretmenlik-Eğitim Bilimleri: & Sosyal $\mathrm{r}=$ & $\frac{17.280-10.075,20}{4(10.075,20+13.695,72)}=0.075$ \\
\hline Tip: & Sosyal $r=$ & $\frac{24.408-10.075,20}{6(10.075,20+22.272,72)}=0.073$ \\
\hline Hukuk: & Sosyal r= & $\frac{17.340-10.075,20}{4(10.075,20+13.857,72)}=0.076$ \\
\hline İşletme: & Sosyal $r=$ & $\frac{14.916-10.075,20}{4(10.075,20+13.857,72)}=0.050$ \\
\hline Elektrik-Elektronik: & Sosyal $\mathrm{r}=$ & $\frac{19.584-10.075,20}{4(10.075,20+14.334,72)}=0.097$ \\
\hline Uluslararası İlişkiler: & Sosyal $\mathrm{r}=$ & $\frac{19.560-10.075,20}{4(10.075,20+13.857,72)}=0.099$ \\
\hline Bilgisayar Mühendisliği: & Sosyal $\mathrm{r}=$ & $\frac{18.384-10.075,20}{4(10.075,20+14.334,72)}=0.085$ \\
\hline Endüstri Mühendisliği: & Sosyal r= & $\frac{17.640-10.075,20}{4(10.075,20+14.334,72)}=0.077$ \\
\hline İnşaat Mühendisliği: & Sosyal $\mathrm{r}=$ & $\frac{23.436-10.075,20}{4(10.075,20+14.334,72)}=0.137$ \\
\hline Makine Mühendisliği: & Sosyal r= & $\frac{24.516-10.075,20}{4(10.075,20+14.334,72)}=0.148$ \\
\hline İktisat: & Sosyal $\mathrm{r}=$ & $\frac{17.160-10.075,20}{4(10.075,20+13.857,72)}=0.074$ \\
\hline Mimarlık: & Sosyal $\mathrm{r}=$ & $\frac{19.272-10.075,20}{4(10.075,20+14.334,72)}=0.094$ \\
\hline Mütercim-Tercümanlık: & Sosyal $\mathrm{r}=$ & $\frac{17.724-10.075,20}{4(10.075,20+14.015,72}=0.079$ \\
\hline Matematik: & Sosyal $\mathrm{r}=$ & $\frac{16.956-10.075,20}{4(10.075,20+14.015,72)}=0.071$ \\
\hline Müzik: & Sosyal r= & $\frac{15.132-10.075,20}{4(10.075,20+13.695,72)}=0.053$ \\
\hline
\end{tabular}

Sonuçlara göre sosyal getiri oranının en düşük çıktığı iki bölüm işletme ve müziktir. Bu iki bölümün ardından matematik, iktisat bölümlerinde de oranlar diğer bölümlere göre düşüktür. En yüksek sosyal getiri oranları mühendislik bölümlerinde ortaya çıkmıştır.

\section{Bireylerin Belirlenmiş Üniversite Bölümlerine Yaptığı Toplam Harcamalar ile Getirilere İlişkin Bulgular}

Eğitimin doğrudan bireysel maliyetleri hesaplanırken 1997 yılının aylık ortalama öğrenci harcaması olan 16 milyon lira öncelikle 2005 yılının şubat ayındaki TÜFE'ye endekslenmiştir. 1997 yılının mayıs ayındaki TÜFE endeksi 321, 2005 Şubatındaki endeks ise 5.163'tür. Yani o günkü aylık öğrenci harcaması günümüze kadar 16.08 kat artmıştır. Bu durumda 1997 yılındaki 16 milyon TL'nin günümüzdeki karşılığı şöyle bulunur:

$$
16 \text { milyon TL } \times 16,08=257,28 \text { YTL }
$$

Bir öğretim yılının 9 ay olduğu düşünüldüğünde seçilmiş bütün bölümlerden mezun olan bir öğrencinin 4 yıllık doğrudan harcamaları toplamı da tablo 7'de gösterilmektedir. Buna göre doğrudan bireysel maliyetler şöyle hesaplanmıştır:

$$
9 \text { × 257,28 x eğitim süresi }
$$

Dolaylı bireysel maliyet hesaplamasında ise 12 aylık vazgeçilen kazanç alınmıştır. Bu durumda yıllık vazgeçme maliyeti, 13/1'nde çalışan lise mezununun net maaşı olan aylık 525,76 YTL'den yıllık 6.309,12 YTL'dir. Hesaplama mantığı yukarıdaki gibidir ve ilgili veriler Tablo 7' de gösterilmektedir.

Tablo VII

\begin{tabular}{|c|c|c|c|c|}
\hline Bölümler & $\begin{array}{c}\text { Toplam Doğrudan } \\
\text { Bireysel Maliyet }\end{array}$ & $\begin{array}{c}\text { Toplam Dolaylı } \\
\text { Bireysel Maliyet }\end{array}$ & $\begin{array}{c}\text { Aylık Ortalama } \\
\text { Kazançlar }\end{array}$ & $\begin{array}{c}\text { Yıllık Ortalama } \\
\text { Kazançlar }\end{array}$ \\
\hline Öğretmenlik-Ĕ̆itim Bilimleri & 9.262 .08 & $25.236,48$ & $1.440,00$ & 17.280 \\
\hline Tıp Fakültesi & 13.893 .12 & $37.854,72$ & $2.034,00$ & 24.408 \\
\hline Hukuk Fakültesi & 9.262 .08 & $25.236,48$ & $1.445,00$ & 17.340 \\
\hline İşletme Bölümü & 9.262 .08 & $25.236,48$ & $1.243,00$ & 14.916 \\
\hline
\end{tabular}

Bireysel Maliyetler ve Kazançlar 
Yüksel YEŞİLBAĞ

\begin{tabular}{lcccc}
\hline $\begin{array}{l}\text { Elektrik-Elektronik Mühendisliği } \\
\text { Bölümü }\end{array}$ & 9.262 .08 & $25.236,48$ & $1.632,00$ & 19.584 \\
\hline Uluslararası İlişkiler Bölümü & 9.262 .08 & $25.236,48$ & $1.630,00$ & 19.560 \\
\hline Bilgisayar Mühendisliği Bölümü & 9.262 .08 & $25.236,48$ & $1.532,00$ & 18.384 \\
\hline Endüstri Mühendisliği Bölümü & 9.262 .08 & $25.236,48$ & $1.470,00$ & 17.640 \\
\hline İnşaat Mühendisliği Bölümü & 9.262 .08 & $25.236,48$ & $1.953,00$ & 23.436 \\
\hline Makine Mühendisliği Bölümü & 9.262 .08 & $25.236,48$ & $2.043,00$ & 24.516 \\
\hline İktisat Bölümü & 9.262 .08 & $25.236,48$ & $1.430,00$ & 17.160 \\
\hline Mimarlı Bölümü & 9.262 .08 & $25.236,48$ & $1.606,00$ & 19.272 \\
\hline Mütercim-Tercümanlık Bölümü & 9.262 .08 & $25.236,48$ & $1.477,00$ & 17.724 \\
\hline Matematik Bölümü & 9.262 .08 & $25.236,48$ & $1.413,00$ & 16.956 \\
\hline Müzik Bölümü & 9.262 .08 & $25.236,48$ & $1.261,00$ & 15.132 \\
\hline Toplam (Ortalama) & $\mathbf{9 . 5 7 0 , 8 1}$ & $\mathbf{2 6 . 0 7 7 , 6 9}$ & $\mathbf{1 . 5 7 3 , 9 3}$ & $\mathbf{1 8 . 8 8 7 , 2 0}$ \\
\hline
\end{tabular}

Eldeki verilerle bireysel getiri oranı aşağıdaki gibi hesaplanmaktadır.

$\begin{array}{lll}\text { Öğretmenlik-Ĕ̆itim Bilimleri: } & \text { Bireysel } r= & \frac{17.280-6.309,12}{4 \times 17.280}=0.158 \\ \text { Tip: } & \text { Bireysel } r= & \frac{24.408-6.309,12}{6 \times 24.408}=0.123 \\ \text { Hukuk: } & \text { Bireysel } r= & \frac{17.340-6.309,12}{4 \times 17.340}=0.159 \\ \text { İşletme: } & \text { Bireysel } r= & \frac{14.916-6.309,12}{4 \times 14.916}=0.144 \\ \text { Elektrik-Elektronik: } & \text { Bireysel } r= & \frac{19.584-6.309,12}{4 \times 19.584}=0.169 \\ \text { Uluslar arası İlişkiler: } & \text { Bireysel } r= & \frac{19.560-6.309,12}{4 \times 19.560}=0.169 \\ \text { Bilgisayar Mühendisliği: } & \text { Bireysel } r= & \frac{18.384-6.309,12}{4 \times 18.384}=0.164 \\ \text { Endüstri Mühendisliği: } & \text { Bireysel } r= & \frac{17.640-6.309,12}{4 \times 17.640}=0.160 \\ \text { İnşaat Mühendisliği: } & \text { Bireysel } r= & \frac{23.436-6.309,12}{4 \times 23.436}=0.182 \\ \text { Makine Mühendisliği: } & \text { Bireysel } r= & \frac{24.516-6.309,12}{4 \times 24.516}=0.185 \\ \text { İktisat: } & \text { Bireysel } r= & \frac{17.160-6.309,12}{4 \times 17.160}=0.158 \\ \text { Mimarlık: } & \text { Bireysel } r= & \frac{19.272-6.309,12}{4 \times 19.272}=0.168 \\ \text { Mütercim-Tercümanlık: } & \text { Bireysel } r= & \frac{17.724-6.309,12}{4 \times 17.724}=0.161 \\ \text { Matematik: } & \text { Bireysel } r= & \frac{16.956-6.309,12}{4 \times 16.956}=0.157 \\ \text { Müzik: } & \text { Bireysel } r= & \frac{15.132-6.309,12}{4 \times 15.132}=0.145\end{array}$

Görüldüğü gibi bireysel getiri oranları bütün bölümlerde \%10'un üstündedir. En yüksek bireysel getiri oranları inşaat mühendisliği, makine mühendisliği ve diğer mühendislik bölümlerinde görülmüştür. Sonuçlara göre müzik ve işletme bölümlerindeki bireysel getiri oranları tüm bölümlerden düşüktür.

\section{Tüm Bölümler Genelinde Üniversite Eğitiminin Sosyal ve Bireysel Getirilerine İlişkin Bulgular}

Üniversite yatırımlarının sosyal getirileri önce kısa-yol formülü ile hesaplanmakta daha sonra faydamaliyet oranı bulunmaktadır. Kısa-yol ve fayda-maliyet oranı formüllerinde kullanılan $E$, adı geçen eğitim düzeyindeki ( $\mathrm{u}=$ üniversite ve $\mathrm{s}=$ lise) bir bireyin yıllık ortalama kazancını; 4, üniversite eğitiminin uzunluğunu; $C_{u}$, üniversite eğitiminin yıllık doğrudan maliyetini ifade etmektedir.

$$
\begin{aligned}
& \bar{E}_{u}=1573,93 \times 12=18.887,20 \\
& \bar{E}_{s}=839,60 \text { (brüt ücret) } \times 12=10.075,20 \\
& C_{u}=14.608,98
\end{aligned}
$$

Bireysel getiri oranı hesaplanırken net ücret olan 525,76x12=6.309,12 kullanılmıştır.

Kısa yol formülünde ihtiyaç duyulan veriler Tablo 6 ve Tablo 7'den elde edilebilir. 
Türkiye Yükseköğretim Sisteminde Eğitimin Getirileri

$$
\begin{array}{ll}
\text { Sosyal } r= & \frac{\bar{E}_{u}-\bar{E}_{S}}{4\left(\bar{E}_{s}+C_{u}\right)}=\frac{18.887,20-10.075,20}{4(10.075,20+14.608,98)}=0.089 \\
\text { Bireysel } r= & \frac{\bar{E}_{u}-\bar{E}_{S}}{4\left(\bar{E}_{u}\right)}=\frac{18.887,20-6.309,12}{4 \times 18.887,20}=0.166
\end{array}
$$

Sosyal getiri oranının dışında sosyal fayda-maliyet oranı aşağıdaki gibi hesaplanmaktadır. Bu hesaplamada uzun dönemli veriler mevcut olmadığı için kazançların 43 yıl boyunca sabit kalacağı varsayılmaktadır. Bu durumda üniversite mezunu ile lise mezunu arasındaki yaşam boyu brüt kazanç farkı yükseköğretimin sosyal faydasını oluşturmaktadır. Brüt ücret, bir üniversite mezununun ortalama aylık net ücretine göre hesaplanmaktadır. Sosyal maliyet ise yıllık 14.608,98 YTL'den 4 yıllık 58.435,92 YTL eder. Öyleyse aylık ortalama kazançlar yıllık ve daha sonra da 43 yıllık kazanca dönüştürülmüştür. Aynı durum bireysel fayda-maliyet oranında da yapılmışır.

$$
\begin{aligned}
& \text { Sosyal fayda/maliyet }=\frac{\bar{E}_{u}-\bar{E}_{S}}{C_{u}}=\frac{1.130 .870,76-433.233,60}{58.435,92}=11,93 \\
& \text { Bireysel fayda/maliyet }=\frac{\bar{E}_{u}-\bar{E}_{S}}{C_{u}}=\frac{812.149,60-271.292,16}{35.648,5}=15,17
\end{aligned}
$$

Genel olarak üniversite yatırımlarının sosyal getirisi \%8,9, bireysel getirisi ise $\% 16,6$ bulunmuştur. Faydamaliyet oranlarında ise sosyal açıdan 11,93, bireysel açıdan da 15,17'lik bir rakama ulaşılmıştır.

\section{Cinsiyete Göre Sosyal ve Bireysel Getiriler Arasındaki Farklılığa İlişkin Bulgular}

Cinsiyete göre alınan ortalama aylık kazançlar Tablo 8'de gösterilmektedir. Bu tablodan yararlanarak

\begin{tabular}{|c|c|c|c|c|c|}
\hline \multirow{2}{*}{ Bölümler } & & \multicolumn{2}{|c|}{ Cinsiyet } & \multicolumn{2}{|c|}{ Ortalama Kazançlar } \\
\hline & & Kadın & Erkek & Kadın & Erkek \\
\hline Öğretmenlik-Eğitim Bilimleri & & 29 & 34 & 1.417 & 1.447 \\
\hline Tip & & 23 & 41 & 1.824 & 2.152 \\
\hline Hukuk & & 22 & 39 & 1.350 & 1.499 \\
\hline İşletme & & 33 & 24 & 1.188 & 1.319 \\
\hline Elektrik-Elektronik Mühendisliği & & 13 & 34 & 1.712 & 1.601 \\
\hline Uluslararası İlişkiler & & 17 & 21 & 1.853 & 1.450 \\
\hline Bilgisayar Mühendisliği & & 16 & 23 & 1.656 & 1.446 \\
\hline Endüstri Mühendisliği & & 28 & 31 & 1.516 & 1.429 \\
\hline İnşaat Mühendisliği & & 14 & 61 & 1.871 & 1.971 \\
\hline Makine Mühendisliği & & 14 & 30 & 1.929 & 2.097 \\
\hline İktisat & & 30 & 36 & 1.160 & 1.654 \\
\hline Mimarlık & & 29 & 23 & 1.250 & 2.054 \\
\hline Mütercim-Tercümanlık & & 26 & 16 & 1.369 & 1.653 \\
\hline Matematik & & 19 & 24 & 1.345 & 1.467 \\
\hline Müzik & & 27 & 18 & 1.287 & 1.222 \\
\hline \multicolumn{4}{|c|}{ Toplam (Ortalama) } & 1.515 & 1.631 \\
\hline & Kadınlar için $r=$ & \multicolumn{4}{|c|}{$\frac{18.180-6.309,12}{4 \times 18.180}=0.163$} \\
\hline & Erkekler için $r=$ & \multicolumn{4}{|c|}{$\frac{19.572-6.309,12}{4 \times 19.572}=0.169$} \\
\hline
\end{tabular}
kadın ve erkeklerin getiri oranları genel olarak aşağıdaki gibi hesaplanabilir.

Tablo VIII

Cinsiyete Göre Ortalama Kazançlar

$\mathrm{Bu}$ formülde kadınların ve erkeklerin aylık ortalama kazançları 12 ile çarpılarak yıla çevrilmiştir. Getiri oranlarında cinsiyete göre anlamlı bir farklılığa rastlanmamıştır. Getiriler kadınlar için \%16,3, erkekler için $\% 16,9$ 'dur.

\section{Sonuç ve Tartışma}

Araştırmada sosyal getiri oranının en düşük çıktı̆̆ı iki bölüm, işletme ve müzik eğitimidir. Bu sonucun en önemli nedeni, bu iki bölümden mezun olan bireylerin yıllık kazançlarının, diğer bölümlere göre daha düşük olmasıdır. İşgücü piyasasındaki işletme ve müzik eğitimi mezunları arzının yüksek olmasına karşılık talebin aynı büyüklükte olmamasının, özellikle kamu üniversitelerindeki bu iki bölümden mezun olanların hem iş 
bulma olasılıklarını azalttığı hem de bulunan işte düşük ücret alma olasılıklarını artırdığı söylenebilir. Bu durum, kamunun bu bölümlerden mezun olanlar üzerinden kazandığı vergilerin düşük olmasına yol açmaktadır. Aynı durum kuşkusuz birincil işgücü piyasasına girmek için gerekli olmayabilecek diplomalar verdiği için iktisat ve matematik bölümleri için de söylenebilir ki bu bölümlerin getiri oranlarının da düşük olması bunu doğrulamaktadır. Bundan başka, genel olarak sosyal getiri oranı ortalamasının üstünde olan bölümlerin genelde mühendislikler olarak görülmesi beklenen bir sonuçtur. Bu durumda ülkenin eğitiminsangücü-istihdam yapısı da göz önünde bulundurularak mimarlık ve mühendislik bölümlerinde yükseköğretime daha fazla kamusal yatırım yapılmasının kârlı olacağı söylenebilir.

Bilindiği gibi sosyal getiri oranı kamu açısından eğitim yatırımlarının maliyet ve faydalarını özetlemektedir. Başka bir deyişle hesaplanan oranlar, eğitimin tüm kaynak maliyetlerini içermektedir. Aslında aşağıda verilen bireysel getiri oranları ile karşılaştıııldığında sosyal getiri oranlarının düşük çıkmasının temel nedeni de burada kullanılan maliyetlerin bireysel maliyetlerden daha büyük olmasıdır. Sonuçlardan anlaşıldığı gibi genelde bütün bölümlerde sosyal getiri oranları birbirine çok yakındır. İnşaat ve makine mühendisliği dışında diğer tüm bölümlerin sosyal getiri oranları \%10'un altındadır. Aslında bu bulgular Psacharopoulos (1993) tarafından değişik ülkelerde farklı alanların getiri oranı hesaplamasındaki birçok sonuç ile benzerlikler göstermektedir. Örneğin, Kanada'da sosyal bilimler alanı için sosyal getiri oranı $1985^{\prime}$ te \%8,8; ekonomi (iktisat) için 1967'de \%9; mühendislikler için \%11,7; mimarlık için \%4,5; sosyal bilimler alanında Büyük Britanya' da bu oranlar 1967 yılı için \%13; 1971 yılı için \%11; mühendislik ve teknoloji alanında 1971 yılı için $\% 6^{\prime}$ dır.

Esasında kuramsal olarak sosyal getiri oranlarının düşük çıktığı bölümler, kamusal olarak kâr elde edilemeyen, yüksek çıtığı bölümler ise kazanç sağlanan bölümler olarak yorumlanmaktadır ve düşük kâr getiren bölümlere kamu yatırımının rasyonel olmadığı söylenmektedir. Birçok gelişmemiş ya da azgelişmiş ülkede olduğu gibi Türkiye için de böyle bir yorum yapmak doğru olmayabilir. Örneğin toplumda yaşayan insanların sağlı̆̆ı, kamunun korumakla yükümlü olduğu temel alanların en önemlilerindendir. Bir kişinin salgın hastalığa yakalanması bile birçok insanı etkileyebilecek bir durumdur. Bu durumda tıp fakültelerinin kamusal getirilerinin düşük olması, bu bölümlere kaynak ayrılmasını engelleyebilecek bir gösterge değildir. Salgın hastalığa yakalanan kişinin sağlık hizmetinin maliyetini karşılayamayacak düzeyde olduğu düşünüldügünde bu yatırımın önemi açık biçimde ortaya çıkmaktadır. Aslında getiri oranlarının düşük çıktığı diğer bölümler için de aynı mantık ileri sürülebilir. Toplumların gelişmesinde eğitimin önemli bir rolü olduğu genelde kabul gören bir düşüncedir. Bu durumda örgün eğitimde sınıf içi etkileşimin en önemli unsuru olan öğretmenlerin çağın gereklerine uygun biçimde yetiştirilmesi bir zorunluluk halini almaktadır. Öyleyse getiri oranı çok düşük diye bu bölüme ayrılacak kaynakların diğer herhangi bir alana ayrılması belki de hükümetlerin kendi insanlarına ve geleceğine yapabileceği en büyük kötülüktür.

Öncelikle yükseköğretimde bireysel getirilerin sosyal getirilerden daha yüksek olacağını ileri süren kuramla da tutarlı olarak bütün bölümlerde getiri oranları \%10'un üstündedir. En büyük bireysel getiri aylık kazancın yüksek olduğu bölümlerde görülmektedir. Örneğin inşaat mühendisliği, makine mühendisliği ve diğer mühendislikler ile uluslararası ilişkiler ve hukuk bölümlerinde bireysel getiriler diğerlerinden biraz daha yüksektir. Bireysel getirinin yüksek olması bu bölümlerden mezun olan her bireyin işgücü piyasasında kolaylıkla iş bulabildiği ve çok büyük ücretler aldığı anlamına gelmemektedir. Çünkü bu araştırmada yalnızca ücretli olarak çalışanlar ele alınmaktadır. Ortaya çıkan bulgular birey açısından önemli bir gösterge olsa da kamu bütçesinden bu bölümlere ayrılan kaynak birçok gelişmiş ve gelişmekte olan ülkenin ayırdığından daha küçük olduğu bir gerçektir.

Tıp fakültesi mezunları hariç bireysel getiri oranlarının düşük çıtığı diğer bölümlerde aylık kazançların görece daha düşük olduğu görülmektedir. Örneğin müzik bölümünden mezun olan bir kişinin aylık ortalama kazancı diğer tüm bölümlerden mezun olanlarınkinin altındadır. Bu bölümden mezun olanlara ilişkin en dikkat çekici bulgu, ankette 24. soruda sorulan "Ek bir işte çalışıyor musunuz?" sorusuna genelde "evet" cevabı vermeleridir. Araştırma sonucunda bu kişilerin ücretli bulundukları işyerinin dışında ek iş olarak çalıştıkları alan ise bar, kafe gibi eğlence mekânları olarak çıkmıştır. Hesaplamada ortaya çıkan en ilginç bulgu tıp fakültesi mezunları için görülmektedir. Aylık ortalama kazançları makine mühendisliği bölümünden 
sonra en yüksek ikinci meslek grubu olmasına rağmen eğitim sürelerinin 6 yıl olmasından dolayı hesaplanan bireysel getiri \%12,3'tür. Tıp fakültesi mezunlarının çalışma yaşamlarının diğer bölümlere göre iki yıl daha kısa, dolayısıyla vazgeçme maliyetlerinin daha uzun olduğu bir gerçektir. Bu durumda bu bölümden mezun olanların gerekli veriye ulaşılsaydı yaş-kazanç profillerinin dikleşme süresinin diğer alanlara göre daha geç olacağı söylenebilirdi.

Bireysel açıdan en büyük getiri oranlarının, tıp fakültesi hariç, aylık kazançların yüksek olduğu bölümlerde olduğu görülmektedir. Bu durumda örneğin inşaat mühendisliği, makine mühendisliği, elektrikelektronik mühendisliği ve uluslararası ilişkiler bölümleri olmak üzere bütün bölümlerde ortaya çıkan getiri oranlarının, günümüzde banka faiz oranlarının çok üstünde olduğu, bu nedenle tüm bölümlerde yükseköğretim yatırımlarının bireysel açıdan kârlı olduğu söylenebilir.

Sosyal getiri oranlarına genel olarak bakıldığında \%8,9'luk bir sosyal getiri oranı, yükseköğretime kamu tarafından yapılacak bir yatıımdan bir yıl sonra \%8,9'luk bir kazanç sağlayacağı anlamına gelmektedir ki bu rakam, büyük oranda kamu tarafından sunulan eğitim için önemli düzeyde yüksektir. Bununla birlikte yalnızca bu orana bakıldığında ve örneğin devlet tahvillerinin bir yıllık getirisinin \%15 civarında olduğu düşünüldüğünde yükseköğretime yapılan kamusal harcamaların fırsat maliyetinin çok yüksek olduğu ileri sürülebilir. Fakat bu sonucun üniversite eğitiminin sosyal faydalarını yansıtmadığı tekrar hatırlatılmalıdır. Eğer sosyal faydalar bu orana dâhil edilebilseydi sosyal getiri oranının, fiziksel sermaye yatırımlarının ya da devlet tahvillerinin getirisinden daha yüksek çıkacağı söylenebilirdi. Bireysel açıdan düşünüldüğünde ise $\% 16,6^{\prime}$ lık bir getiri oranı, bireyin bankaya 1000 YTL yatırdığında bir yıl sonra 1.166 YTL kazanacağını işaret etmektedir ki bu oran günümüz için banka faizinden daha kârlıdır.

Üniversite eğitiminin bireysel getiri oranının sosyal getiri oranından fazla çıkması, aslında bireysel talebin sosyal talebi aşmasından kaynaklanmaktadır. Yükseköğretime bireysel talebi etkileyen faktörlerden bazılarının ise, üniversite ile daha alt eğitim düzeylerinden mezun olanlar arasındaki kazanç farkı, toplumsal bir statü elde etme isteği, erkekler için askerlikten kaçma ve yedek subaylık şansı yakalama olduğu ileri sürülebilir. Kamunun ise üniversite eğitimine yatırım yaparken parasal beklentisinin yanı sıra sosyal ve kültürel beklentisi, yani eğitimin dışsallıklarından yararlanma isteği söylenebilir.

Yukarıdaki sonuçlar genel olarak değerlendirildiğinde Dünya'da ve Türkiye' de ortaya çıkaran sonuçlarla tutarlılık gösterdiği görülebilir. Örneğin, Blaug (1972) tarafından yapılan getiri oranı hesaplamasında ABD'de bireysel getiri oranlarının sosyal getiri oranlarından yüksek olduğu ortaya çıkmıştır. Blaug ile aynı şeyi söyleyen Cohn ve Geske (1990), ABD'de yapılan tüm çalışmalarda bireysel getiri oranlarının \%10 ile \%15 arasında değişirken sosyal getirilerin bundan daha düşük çıktığını dile getirmişlerdir. Psacharopoulos ve Patrinos (2004) tarafından birçok ülke için yapılan araştırmada da genel olarak düşük gelir (kişi başına gelirin 755 \$ ve altında olan) grubundaki ülkelerde yükseköğretimin sosyal getiri oranı \%11,2; orta gelirli ülkelerde (kişi başına gelirin 9265 \$'a kadar olduğu) bu oran \%11,3; yüksek gelirli ülkelerde de \%9,5 çımıştır. Bu araştırmaya göre Dünya genelinde sosyal getiri oranı \%10,8'dir. Aynı araştırmada bireysel getiriler ise sırasıyla \%26, \%19,3, \%12,4 ve Dünya genelinde de \%19'dur. Bu iki yazar tarafından yapılan adı geçen araştırmada getiri oranlarına ilişkin Ortadoğu'daki sonuçlar da sosyal getiriler için $\% 9,9$, bireysel getiriler için $\% 18,8^{\prime}$ dir.

Getiri oranları konusunda Türkiye'de de $1968^{\prime}$ den bu yana on civarında araştırma yapılmıştır. Bunlardan bazıları ve ortaya çıkardıkları bulgular Tablo 9'da gösterilmektedir. Tablodaki kamu ve özel kavramları, araştırmacının kullandığı verilerin kaynağını göstermektedir.

Türkiye'de yapılan araştırmalara bakıldığında getiri oranlarına ilişkin ilk çalışmanın bir Amerikalı tarafından yapıldığı görülmektedir. Krueger (1972; akt. Akalın, 1980), 1968 yılında Türkiye'de eğitimin getiri oranlarını hesapladığı çalışmasında, eğitim düzeyi yükseldikçe özel getirilerin arttığını söyleyerek yükseköğretimin özel getiri oranını \%25-27, sosyal getiri oranını ise \%8-9 olarak hesaplamıştır. Krueger, çalışmasında maliyet verilerini Eide (1969) tarafından yapılan araştırmaya, kazanç verilerini de 1968'de Madeni Eşya Sanayicileri Sendikası [MESS] ve Amerikan Hava Kuvvetleri tarafından yapılan araştırmalara dayandırmış ve üniversite öğrencilerinin eğitimleri süresince çalıştıklarını ya da karşılıksız burs aldıklarını varsayarak hem vazgeçilen gelirleri hem de doğrudan maliyetlerini dikkate almamıştır. Bu durum, büyük 
oranda gerçeği yansıtmadı̆̆ı için ortaya çıkan sonuçların da yukarıya doğru sapmasına neden olmuştur. Sonuç olarak bu araştırmada Krueger'ın konuya en başından beri farklı bir açıdan yaklaştığı söylenebilir. Çünkü araştırmasının sonucunda vardığı yargıya göre üniversitenin sosyal getiri oranları düşük olduğundan bu bölüme çok fazla kamusal yatırım yapılmamalıdır ve öğrencilerden yüksek oranda harç alınmalıdır

Tablo IX

Türkiye'de Değişik Araştırmalarda Ortaya Çıkan Yükseköğretimin Getiri Oranları

\begin{tabular}{|c|c|c|c|c|}
\hline \multirow{2}{*}{ Araştırmacı } & \multicolumn{2}{|c|}{ Sosyal \% } & \multicolumn{2}{|c|}{ Bireysel \% } \\
\hline & Kamu & Özel & Kamu & Özel \\
\hline Krueger, 1968 & - & 8-9 & - & $25-27$ \\
\hline Özelli, 1970 & $1,5-2,5$ & - & $2,5-3$ & - \\
\hline Akalın, 1980 & 8,3 & - & 10,5 & - \\
\hline Gürer, 1981 & - & - & - & 13,08 \\
\hline Tunç, 1998 & - & - & 14,11 & 23,28 \\
\hline \multirow[t]{2}{*}{ Tansel, 1994} & & & & \\
\hline & & & & 16,2 \\
\hline Kadınlar için & - & - & - & 15,0 \\
\hline (1989 verileriyle) & - & - & - & \\
\hline Erkekler için & & & & 16,90 \\
\hline Kadınlar için & - & - & - & 14,68 \\
\hline (1994 verileriyle) & - & - & & - \\
\hline Tansel, 1999a & & & 16,05 & \\
\hline Kadınlar için & - & - & 17,86 & - \\
\hline \multicolumn{5}{|l|}{ Türkmen, 2002} \\
\hline 1987 verileriyle & - & - & - & 27,6 \\
\hline 1994 verileriyle & - & - & - & 26,5 \\
\hline
\end{tabular}

Türkiye'de yapılan ikinci çalışmada Özelli (1970), 1923-1960 arasındaki dönemi izleyerek yalnızca kamu çalışanlarına ilişkin verileri kullanmış ve yükseköğretimin hem sosyal hem de bireysel getiri oranlarını oldukça düşük bulmuştur. Özelli (1970) araştırmasında sosyal getiriyi \%1,5-2,5; bireysel getiriyi de \%2,5-3,5 olarak hesaplamıştır. Buna karşın ortaöğretimin getiri oranları çok yüksektir (bireysel \%14-19, sosyal \%11-14). Özelli, yaş-kazanç profillerine kamu çalışanlarının maaşları dışında hiçbir ek gelirlerinin olmadığı varsayımıyla çapraz-kesit yöntemi ile ulaşmıştır. Çalışmasının sonucunda ise bu getiri oranlarına göre yükseköğretime daha az, ortaöğretime ise daha fazla kaynak ayrılması gerektiğini ileri sürmektedir. Okullaşma oranları temel ve ortaöğretimde çok düşük olduğundan bu yorumun o günkü koşullar içinde doğru olduğu varsayılabilir.

Akalın (1980) ise 1970 yılına ilişkin kamu çalışanları ile ilgili verileri kullanarak yaptığı hesaplamasında yükseköğretimin sosyal getiri oranını \%8,3, bireysel getiri oranını da \%10,5 olarak bulmuştur. Akalın'ın (1980) çalışmasında bulduğu sonuçlar araştırmacının kullandığı verilerin ve varsayımlarının farklı olması nedeniyle daha önceki iki araştırmanın (Krueger ve Özelli) sonuçlarından oldukça farklı, bu araştırmanın bulgularıyla daha çok benzerdir. Akalın (1980: 133), araştırmasının sonucunda \%8,3'lük bir sosyal getiri oranının kamu açısından sermaye finansman maliyetini yansıttığını söylediği \%6'lık devlet tahvilleri faiz oranından yüksek olduğunu görmüştür. Bununla birlikte o dönemde makine ve teçhizat yatırımlarının getiri oranının \%20-25 civarında olduğunu, bu nedenle kamunun yükseköğretim yerine getiri oranı daha yüksek olan fizikî sermayeye yatırım yapmasının daha rasyonel ve toplumsal etkinliği artııcı bir seçim olacağı yorumunda bulunmaktadır. Ancak bu yoruma göre öncelikle sosyal devlet anlayışı yok sayılmaktadır. Bu öneri kabul edildiğinde yükseköğretimde eşitliğin olduğundan daha da bozulması çok mümkündür. Esasında gelir düzeyi yüksek ülkelerde insan sermayesinin getirileri ile fiziksel sermayenin getirileri birbirine yaklaşmaktayken gelişmekte olan ülkelerde insan sermayesine yatırım yapmanın önemli avantajları olduğu dikkate alınmalıdır.

Fayda-maliyet oranına gelince bu oranın üniversite eğitiminin dışsal verimliliğinin önemli bir göstergesi olduğu bilinmektedir. 11,93'lük bir oran, toplumun elde ettiği faydaların esas olarak üniversite eğitimin maliyetlerini aştığını göstermektedir ki bu durumda bu eğitim düzeyine yapılan yatırımın devlet açısından 
kârlı olduğu söylenebilir. Aynı durum bireyler için de söz konusudur. Fayda-maliyet oranı 15,17 çıkmıştır ve bu oran bir yıllık banka faiz oranından daha büyük olduğu için bireylerin üniversite eğitimine yatırım yapmalarının kazançlı olduğu söylenebilir.

Yukarıda söylendiği gibi hesaplanan fayda-maliyet oranı lise ve üniversite mezunlarının aylık kazançlarının 43 yıl boyunca değişmeyeceği varsayımına dayanmaktadır. Kuşkusuz bu uzun bir süredir, fakat yöntem olarak fayda-maliyet oranında böyle bir varsayımın kabul edilmesinden başka bir seçenek bulunmamaktadır. Bu nedenle ortaya çıkan sonucun aşağıya ya da yukarıya sapabileceği ifade edilmelidir. Bununla birlikte fayda-maliyet oranı 43 yıl için değil de yalnızca 4 yıllık eğitim sonrasında elde edilen kazançlar için hesaplanmış olsaydı yukarıda verilen rakamların bir yıllık karşılıkları yerine konulduğunda sosyal açıdan ortaya 1,11, bireysel açıdan da 1,41 gibi bir rakama ulaşılabilirdi ki fayda-maliyet oranının 1'den büyük olması o yatırımın kârlı olduğunu göstermektedir.

Akalın (1980) aynı çalışmasında Türkiye'de yükseköğretim "karma malının" orta ve üst gelir gruplarının talep ettikleri "üstün bir mal" olduğunu ileri sürmekte ve yorumunu buna göre yapmaktadır. Bu görüş araştırmanın yapıldığı dönem için, üniversitelerin büyük şehirlerde yerleşmiş olması ve maliyetleri (özellikle de vazgeçme maliyeti) nedeniyle belki doğru olabilir fakat 1981 yılından bu yana yükseköğretim hizmetinin, iş olanaklarından daha kolay yararlanabilmek ve daha yüksek kazançlar elde etmek gibi nedenlerle toplumun bütün kesimleri tarafından tercih edilmeye başlandığı söylenebilir. Belki günümüzde alt gelir grubundaki öğrencilerin üniversiteye giriş başarıları düşük olabilir, fakat bunun nedeni bir "tercih" değil, üniversiteye giriş sınavının kendisi ve bu süreçteki (ortaöğretim ve hazırlık dönemi) eşitsizliklerdir. Akalın'ın iddia ettiği gibi kamunun yükseköğretimden desteğini çekmesi, ya öğrencilerden alınacak katkı paylarının artırılması ya da bu alanın özel ya da vakıf sermayelerine bırakılması demektir. Bu ise yukarıda söylendiği gibi eğitimde eşitsizliğinin önünün açılması, dolayısıyla insan sermayesi kuramında da ileri sürüldüğü gibi eğitim ve kazanç arasındaki ilişkiye göre yükseköğretim gören ile göremeyen bireyler arasındaki kazanç eşitsizliklerinin artması anlamina gelmektedir.

Akalın'ın hemen ardından Gürer (1981; akt. Tunç, 1998) yalnızca bireysel getiri oranlarını hesaplamış ve yükseköğretim için bu oranı \%13,08 bulmuştur.

Tunç (1998) da kamu kesimine ilişkin yaptığı hesaplamasında yükseköğretimin bireysel getirisini \%14,11, özel kesimde ise bu oranı \%23,28 olarak hesaplamıştır. Tunç'un yaptığı araştırmada ilkokulun $(\% 17,68)$, ortaokulun $(\% 17,55)$ ve lisenin $(\% 14,36)$ bireysel getirilerinin yükseköğretime göre daha büyük çıkması insan sermayesi kuramının öne sürdüğü hipoteze ters düşmektedir. Bilindiği gibi bu kuramda eğitim düzeyi yükseldikçe bireyin sağlayacağı özel getirilerin de artacağı iddia edilmektedir. Tunç (1998), bu sonucu yükseköğretimin bireye maliyetlerinin diğer eğitim düzeylerine göre daha yüksek olmasına bağlamakta ve kendisinin yalnızca 9 yıllık bir döneme baktığını, daha uzun dönemde bireyin kazanç potansiyelinin yaşla birlikte artacağını varsayarak getiri oranlarının daha da yüksek çıkabileceğini ileri sürmektedir.

Tansel (1994), 1987 yılındaki hanehalkı gelir ve harcama araştırmasında elde edilen verileri kullanarak yaptığı araştırmasında eğitim düzeyi arttıkça eğitimin getirilerinin de arttığını, özellikle kadınların sağladığı getirilerin bütün eğitim düzeyleri için erkeklerinkinden daha yüksek olduğunu görmüştür. Tansel (1999a), sonraki bir araştırmasında ücret ölçeklerinin yapısından dolayı kamuda çalışanların getiri oranlarının özel sektörde çalışanlarınkinden daha düşük olduğunu görmüştür.

Türkmen (2002) ise Tansel (1994, 1999a, 1999b) gibi Devlet İstatistik Enstitüsü [DİE] tarafından 1987 ve 1994 yıllarında yapılan araştırmaları kullanarak yükseköğretimde bireysel getiri oranlarını sırasıyla \%27,6 ve \%26,5 bulmuştur. Bu rakamlar, aynı verilerin kullanılmasına rağmen Tansel'in hesaplamalarının çok üstündedir.

Araştırma sonucunda dikkat çeken önemli bir bulgu da cinsiyete göre getiri oranlarında çok büyük bir farklılı̆̆ı çıkmamış olmasıdır. Üniversite eğitiminin kadınlara sağladığı getiri, hesaplandığı gibi \%16,3, erkeklere sağladığı getiri ise \%16,9'dur. Bu bulgular Tansel (1994, 1999a, 2001)'in bulgularıyla karşılaştırıldığında önemli bir benzerlik olduğu görülmektedir.

Örnekleri verildiği gibi Türkiye ile benzer Gayri Safi Milli Hasılaya [GSMH] sahip olan ülkelerde yapılan 
getiri oranı çalışmalarında kadınların yükseköğretimden elde ettikleri getirilerin erkeklerinkinden daha düşük olduğu görülmektedir. Bu çalışmada ise örneklem grubunda yer alan kadınlar için böyle bir durumun çıkmaması, şaşırtıcı bir şekilde işgücü piyasasında kadınlara karşı en azından ücretlerde bir ayrımcılığın olmadığı biçiminde yorumlanabilir. Bu durum, Türkiye' de yapılan bazı araştırmalarda erkek egemen bakışın tüm toplumsal, ekonomik ve yasal ilişkiler üzerinde önemli bir etkisinin olduğunu, kadınların da doğal olarak bu bakıştan olumsuz etkilendiğini gösteren sonuçlarla çelişmektedir. Genelde "evinin kadını", "çocuğun annesi" olması istenen ve "erkek işine karışması" istenmeyen kadınların okur-yazarlık ve işgücüne katılım oranlarının erkeklere göre düşük olmasına rağmen, çalışan kadınların (özellikle birincil işgücü piyasasında) ücretlerinin erkeklerin aldığı ücretlere yakın olması, kadınların bir avantajı olarak da yorumlanabilir. Ancak bu sonucun, tüm Türkiye'ye genellenemeyecek bir sonuç olduğu da ifade edilmelidir.

Görüldüğü gibi özel sektörde cinsiyetler açısından getiri oranlarında anlamlı bir farklılık ortaya çıkmamıştır, fakat çok küçük oranda da olsa kazançlar açısından kadınların aleyhine bir durum olduğu görülmektedir. Bununla birlikte yükseköğretim yatırımlarının hem kadınlar hem de erkekler için kârlı olduğu söylenebilir. Bu noktada kamunun, her bir bireyin yükseköğrenim görmesini sağlayacak düzenlemelere gitmesi gerektiği ortaya çıkmaktadır. Türkiye'de geçmişten günümüze kadın-erkek arasındaki eğitim eşitsizlikleri birçok çalışmada konu edilmiş, birçok defa vurgulanmıştır. Sayısal göstergelere bakıldığında özellikle okur-yazarlık ve işgücüne katılım açısından var olan eşitsizlik kalkınmakta olan bir ülkenin çözmesi gereken en temel problemlerden biridir.

Özellikle gelişmiş ülkelerde bulunan sonuçlarla karşılaştırıldığında buradaki bulguların önemli oranda yüksek olduğu görülmektedir, fakat bu beklenen bir sonuçtur. Bilindiği gibi ülkenin gelir ve gelişmişlik düzeyi arttıkça insan sermayesi yatırımlarının getiri oranı da düşmektedir. Bunun temel nedeni yükseköğretim gören kişi sayısının fazla olması ve bu ülkelerde işsizlik problemlerinin olmamasıdır. Örneğin Danimarka'da 1990 yılında üniversite eğitiminin erkekler için getirisi \%3,5, kadınlar için \%5,2; Finlandiya'da 1987 yılında bu oranlar sırasıyla \%6,6 ve \%7,7; Norveç' te 1991 yılında \%4,0 ve \%4,2 ve Japonya' da 1980 yılında $\% 5,7$ ve \%5,8'dir (Psacharopoulos ve Patrinos, 2004).

Bu ülkelere oranla daha geri bir durumda olan Güney Kore'de 1971 yılında bu oranlar, \%15,7, \%22,9; Endonezya' da 1986 yilında \%9,0 ve \%10 ve Porto Rico' da 1959 yılında \%21,9 ve \%9'dur. Endonezya' da yapilan başka bir araştırma da kadınların getiri oranlarının daha yüksek olduğunu göstermektedir. Deolalikar (1995), yetişkinlerin kazançlarına ilişkin verilere göre erkeklerin, ortaöğretim ve yükseköğretim düzeylerindeki eğitim getirilerinin kadınlarınkinden daha düşük, bu farklılığın da özellikle meslekî ortaöğretim ve üniversite düzeyinde çok büyük olduğunu söylemektedir. Fakat eğitime katılım açısından kadınların özellikle ortaöğretim ve üstü eğitim düzeylerine katılım oranlarının da düşük olduğu göze çarpmaktadır.

Li (2003) Çin'de yaptığı araştırmasında, önceki araştırmalara göre eğitimin getirilerinin daha yüksek olduğunu görmüştür. Buna göre bütün getiri oranı \%5,4; erkekler için $\% 4,3$ ve kadınlar için $\% 6,9^{\prime}$ dur.

Moock, Patrinos ve Venkataraman (2003) da Vietnam'da yaptıkları araştırmada ek bir eğitim yılının ortalama bireysel getiri oranının \%5 olduğunu ve fazladan bir eğitim yılının, kazançları \%17 artırdığını, bununla birlikte erkeklerin eğitim getirilerinin kadınlarınkinden daha düşük olduğunu görmüşlerdir. Vietnam'da her bir fazladan eğitim süresinin erkekler için getirisi \%3 iken, kadınlar için \%7' dir.

Vietnam ile bir anlamda benzer olan -geçiş ekonomisi olduğu için- Çek Cumhuriyeti'nde de 1996 yılında yapılan bir araştırmaya göre kadınlar eğitim yatırımlarından daha yüksek getiriler almaktadırlar (erkekler \%5,8, kadınlar \%7). 1994 yılında Rusya'da da benzer biçimde erkeklerin eğitim yatırımları getirisi \%6,7, kadınların ki ise \%9,6; Slovakya' da da bu oranlar erkekler için \%4,9, kadınlar için \%5,4'tür (Psacharopoulos ve Patrinos, 2004).

Yukarıda söylenen araştırmalarla birlikte genelde kadınların eğitim getirilerinin erkeklerinkinden yüksek olduğu söylenebilir. Ancak bu tür hesaplamaların işgücü piyasasında çalışan kadınların gözlenen ücretlerine dayandığı ve kadınlar için getiri oranlarının hanehalkı üretimini dikkate almadığı gerçeği unutulmamalıdır.

Getiri oranı hesaplaması hem sosyal hem de bireysel açıdan yükseköğretime yapılan yatırımların kârlılığını ortaya çıkarmayı amaçlamaktadır. Bu hesaplamalarda sonucu önemli oranda etkileyebilecek 
birtakım varsayımlar kabul edilmektedir. Özellikle yaşam boyu kazancı hesaplamak çok zordur. Yapılan çalışmalarda genellikle bir bireyin 22 yaşında üniversiteden mezun olduğu ve 65 yaşında emekli oluncaya kadar çalıştığı kabul edilmektedir. Ancak yükseköğretime giren bireylerin bir kısmının değişik nedenlerden dolayı okuldan mezun olmadan ayrıldığı bilinmektedir. Bu olgu getiri oranı hesaplamasında çok ciddî bir problem değildir. Fakat öğrenim süresinin uzaması, daha açık deyişle 4 yıllık bir bölümün daha uzun sürede bitirilmesi özellikle maliyetleri (hem sosyal hem de bireysel) artırmaktadır. Hesaplamada buna ilişkin bir düzenleme yapmak ise kamu tarafından bu konuda toplanmış veri olmadığı için Türkiye'deki araştırmacılar açısından çok zordur.

Bu çalışmada karşı karşıya gelinen başka bir nokta, yaşam boyu kazançların ne kadarının yükseköğretime bağlı olduğunun belirlenememesidir. Tahmin edilebileceği gibi kazançların yalnızca bir kısmı üniversite eğitimi ile ilişkilidir ve bunun ne olduğunu tam olarak belirlemek de zordur. Kazanç belirleyici tek faktörün eğitim olmadığı insan sermayesi kuramcıları tarafından da kabul edilmektedir. Fakat getiri oranı hesaplamalarında kazanç üzerinde nasıl bir etkisi olduğu bilinmeyen "gözlenemeyen değişkenlerin" yeterince dikkate alınmaması, hesaplanan getiri oranlarının olduğundan daha yüksek çıkmasına, dolayısıyla eğitimin gelir ya da kazançlar üzerindeki rolünün abartılmasına yol açmaktadır. Bu çalışmada da 15 değişik bölüm için yapılan özel ve sosyal getiri oranı ile fayda-maliyet oranı hesaplamalarında ortaya çıan bulgunun yalnızca bir tahminden ibaret olduğu söylenmelidir. Bu tür hesaplamalarda bütün istatistiksel yöntemlerde olduğu gibi bireylerin eğitim harcamalarının ve mezuniyet sonrasında elde ettikleri kazançların bir "ortalama" olarak alınması da sonuçların gerçekte olduğundan daha farklı (düşük ya da yüksek) çıkmasına neden olabilmektedir.

Hesaplamadaki önemli bir zorluk da uzun vadede Türkiye'nin ekonomik büyümesinin ne olacağının bilinmemesidir. Getiri oranı hesaplamasında geçmiş ve bugün, olduğu gibi yansıtılabilmektedir, fakat gelecek konusunda bireysel açıdan olduğu gibi sosyal açıdan da bir belirsizlik vardır. Hesaplamada gelecekte her hususun bugünkü gibi olacağı varsayılmaktadır. Örneğin emeklilik yaşı belki de gelecekte 65 olmayacaktır, ileride ortalama insan ömrü daha da kısalacak ya da uzayacaktır. Ayrıca Türkiye'nin ekonomik açıdan istikrarlı bir ülke olmadığı gerçeğiyle gerek vazgeçme maliyetinin alınmasında gerekse yapılan doğrudan maliyetler ile kazançların/ücretlerin belirlenmesinde önemli zorluklar yaşanmaktadır. Daha açık deyişle üniversite öğrencilerinin aylık harcaması olarak alınan rakamın ve bireyin işgücü piyasasında aldığ bir ortalama olması yöntem açısından bir problem teşkil etmektedir. Bununla birlikte bir getiri oranı hesaplamasında başka bir yöntemin kullanılamadığı gerçeği de hesaba katılmalıdır.

$\mathrm{Bu}$ çalışmada getiri oranları hesaplanırken üniversite mezunları arasındaki işsizlik oranları dikkatle incelenmiş ve vazgeçme maliyeti olarak kamuda lise mezunlarına ödenen maaşlar alınmıştır. Burada da bir varsayım söz konusudur. Şöyle ki DİE'nin 2004 yılı için açıkladığı yükseköğretim mezunları arasındaki işsizlik oranı \%12,4'tür. Bu noktada yapılan getiri oranı hesaplamalarında işsizlik olasılığının da düzenlenmesi gerekmektedir, fakat bu çalışmada vazgeçme maliyeti alınırken böyle bir düzenleme yapılmamıştır. Ayrıca bireyin 18 yaşında üniversiteye gireceği, normal eğitim süresi içerisinde mezun olarak işgücü piyasasına adım atacağı ve 65 yaşına kadar çalışacağı varsayılmaktadır. Bireyin okulunu uzatması hem kendisi hem de kamu açısından ek maliyet demektir, fakat bunlarla ilgili veriler mevcut olmadığı için herhangi bir düzeltme yapılmamıştır.

Araştırmanın sonucunu etkileyebilecek başka bir problem de bireyin üniversite eğitimini tamamladıktan sonra ne kadar süre içinde bir işe gireceğinin bilinmemesidir. Yukarıda söylenenler gibi bu da getiri oranı hesaplamalarının en zayıf yönlerinden biridir. Bu nedenle yalnızca "iş bulabilmiş" mezunlara odaklanılmış, ayrıca belli mesleklerde (tıp, öğretmenlik, bazı mühendislikler gibi) kayıt dışı ekonomiden ortaya çıkan para sonuçlara yansıtılamamıştır.

Yukarıda ifade edilen tüm sınırlılıklarına rağmen ortaya çıkan bulguların kamunun ve bireylerin eğitim yatırımı yapma kararı almalarında önemli bir gösterge olabileceği söylenmelidir. Sosyal getiri oranlarının aslında düşük görülmesine rağmen kurama da dayanarak Türkiye için hiç de küçük olarak yorumlanamayacağı belirtilmelidir. Psacharopoulos ve Patrinos'un (2004) söyledikleri gibi sosyal getiriler açısından ülkeler arasında ciddi farklılıklar olmamakla birlikte orta gelirli ülkelerde yükseköğretimin sosyal 
getirileri \%11,3 civarındadır ve bu oran, yükseköğretime yatırım yapmanın sosyal açıdan kârlı olduğunu doğrulamaktadır. Tekrar söylemekte fayda var ki, ortaya çıkan sosyal getiri oranı, üniversite eğitiminin sosyal faydalarını yansıtmamaktadır. Yani yükseköğretimin, suç ve doğum oranlarının azalması, teknolojik gelişmeyi hızlandırması, toplumun kültürel yapısının olumlu anlamda değişmesi gibi birçok konuda önemli katkısı olduğu düşünüldüğünde ve tüm bu katkıların ne düzeyde olduğunun belirlenmesinin mümkün olmadığı gerçeği dikkate alındığında ortaya çıkarılan rakama rağmen kamunun yükseköğretimin tüm bölümlerine yatırım yapmasının toplum açısından gerekli olduğu söylenebilir.

Türkiye'de yükseköğretim büyük oranda "parasızdır" denilse de bu çalışmada bunun böyle olmadığı ortaya çıkmıştır. Yükseköğretimin (yalnızca incelenen 15 bölüm için) sosyal maliyeti öğrenci başına yıllık 14.608,98 YTL iken bireysel maliyeti bu oranın \%61'idir (8.912,12 YTL). Yükseköğretimde özellikle yoksulların aleyhine olan bu durumun düzeltilmesi için bu gruplar lehine birtakım düzenlemelerin acilen yapılması gerekmektedir. Eğitim ve kazançlar arasında bir ilişki olduğu iddia ediliyorsa yoksul aile çocuklarının üniversite eğitiminden yararlanamamaları, yoksul-zengin arasındaki gelir dengesizliğini (en azından kazançlar açısından) daha da derinleştirecektir.

Yükseköğretimin özel getirilerinin bireyin üniversiteye gitme kararında önemli olduğu bilinmektedir. Benzer şekilde yükseköğretim de dâhil genel olarak tüm eğitim tür ve düzeylerinin çeşitli dışsallıkları/sosyal faydaları olduğu gerçeğiyle kamunun bu alanlara yeterli yatırımı yapması toplumsal bir sorumluluk ve zorunluluktur. Başka bir deyişle hükümetler hangi eğitim tür ve düzeyine ne kadar kaynak ayıracağına karar verirken bu hizmetin getiri oranlarına bakmakla birlikte eğitimin sosyal faydalarını mutlaka göz önünde bulundurmalıdir.

Getiri oranı hesaplamasında çapraz-kesit verilerin kullanılması, sonuçların güvenirliği hakkında bazı eksiklikler/sapmalar içermektedir. Bu nedenle devletin düzenli olarak toplayacağı uzun dönemli eğitim-yaşkazanç bilgileriyle doğru bilgilere ve sonuçlara ulaşabilmek daha mümkündür.

Özellikle kamu sektöründe getiri oranlarının hesaplanabilmesi için gerekli verilerin ilgili birimlerce toplanması ve bunların her yıl yayınlanması çok önemlidir. Bilindiği gibi Türkiye'de bilgiye ulaşmada çok ciddî bürokratik engeller mevcuttur. Bu durum mutlaka ortadan kaldırılmalıdır.

Sosyal getiri oranlarının düşük çıtığı tıp, öğretmenlikler gibi bölümlerde karar alıcılar acilen düzenlemeler yapmalıdırlar. Bu bölümlerin Türkiye'de ekonomik kârlılıklarının dışında toplumsal ve kültürel gelişmeye ciddî katkı sağladıkları dikkate alınmalıdır. Bunun yanı sıra teknolojik gelişmedeki katkısı nedeniyle özellikle mühendislik bölümlerine daha fazla kaynak ayrılmalıdır.

Bu çalışmada yalnızca yükseköğretimdeki 15 bölümün sosyal ve bireysel getiri hesaplaması İstanbul'da ücretli çalışan bireyler üzerinde yapılmıştır. Bu hesaplamalar tüm Türkiye çapında ve bütün eğitim tür ve düzeylerinde daha geniş bir örneklem üzerinde yapılmalıdır.

Kamu sektöründe çalışanlar üzerinde de getiri oranları mutlaka doğru biçimde hesaplanıp hem kamuda hem de özel sektörde ortaya çlkarılan önceki bulgularla karşılaştırmalar yapılmalıdır.

Bilindiği gibi getiri oranları, karar almada kullanılan tek yöntem değildir. Buna göre tüm eğitim tür ve düzeylerinde diğer karar alma yöntemleriyle kârlılık analizleri yapılmalıdır.

\section{Yazar(lar)ın Beyanı}

Araştırmacıların katkı oranı beyanı: Araştırmanın tüm aşamaları yazar tarafından yapılmıştır.

Çatışma beyanı: Araştırmada, yazarın kendi içinde ve diğer kişi/kurum/kuruluşlarla herhangi bir çıkar çatışması söz konusu değildir.

Destek ve teşekkür: Çalışmada herhangi bir kurum ya da kuruluştan destek alınmamıştır.

\section{Kaynaklar}

Akalın, G. (1980). Yükseköğretim karma malına maliyet-fayda analizinin uygulanması (Ankara Üniversitesi Siyasal 
Türkiye Yükseköğretim Sisteminde Eğitimin Getirileri

Bilgiler Fakültesi Yayınları No:444). Ankara: Ankara Üniversitesi Basımevi.

Blaug, M. (1972). An introduction to the economics of education. Barmondsworth: Penguin Books.

Cohn, E. ve Geske, T. G. (1990). The economics of education. New York: Pergamon Press.

Deolalikar, A. B. (1995), Gender differences in the returns to schooling and in school enrollment rates in Indonesia. T. Paul Schultz (Ed.), Investment in women's human capital (ss. 273-303) içinde. Chicago: The University of Chicago Press.

Eide, K. (1969). The cost structure of Turkish Higher Education (No. 822). Ankara: DPT Yayın.

Gürer, B. (1981). Eğitim harcamalarının verimliliği (No: 1754). Ankara: DPT Yayın.

Karasar, N. (2014). Bilimsel Araştırma Yöntemleri. Ankara: Nobel Yayın Dağıtım.

Krueger, A. O. (1968). Factor endowment and per capita income differences among countries. The Economic Journal, 78(311), 641-659.

Li., H. (2003). Economic transition and returns to education in China. Economics of Education Review, 22(3), 317328.

Moock, P. R., Patrinos, H. A. ve Venkataraman, M. (2003), Education and earnings in a transition economy: The case of Vietnam. Economics of Education Review, 22(5), 503-510.

Özelli, M. T. (1970). The estimates of private internal rates of return on educational investment in the first Turkish Republic: 1923-1960. International Journal of Middle East Studies, 1(2), 154-176.

Patrinos, H. A. (1994). Notes on education and growth: Theory and evidence (Human Resources Development and Operations Policy HRO Working Papers No.39). Washington DC: The World Bank.

Psacharopoulos, G. (1993). Returns to investment in education: A global update (Policy Research Working Papers No. 1067). Washington, DC: The World Bank.

Psacharopoulos, G. ve Patrinos, H.A. (2004). Returns to investment in education: A further update (Policy Research Working Papers No. 2881). Washington, DC: The World Bank.

Tansel, A. (1994). Wage employment, earnings and returns to schooling for men and women in Turkey. Economics of Education Review, 13(4), 305-320.

Tansel, A. (1999a). Public-private employment choice, wage differentials and gender in Turkey (Economic Growth Center Discussion Paper No. 797). New Heaven: Yale University.

Tansel, A. (1999b). Türkiye ve seçilmiş ülkelerde eğitimin getirisi. ODTÜ Gelişme Dergisi, 26(3-4), 453-472.

Tansel, A. (2001). Self-employment, wage-employment, and returns to schooling by gender in Turkey, D. Salehi-Isfahani (Ed.), Labor and human capital in the Middle East: Studies of markets and household behavior (ss. 337-367) içinde. UK: Ithaca Press.

Tunç, M. (1998). Kalkınmada insan sermayesi: İç getiri oranı yaklaşımı ve Türkiye uygulaması. DEÜ İ̈BF Dergisi, 13(1), 83-106.

Türkmen, F. (2002). Eğitimin ekonomik ve sosyal faydalar ve Türkiye'de eğitim ekonomik büyüme ilişkisinin araştırılması (DPT Uzmanlık Tezleri Yayın No: 2655). Ankara.

Yazıcıoğlu, Y. ve Erdoğan, S. (2004), SPSS uygulamalı bilimsel araştırma yöntemleri. Ankara: Detay Yayıncılık.

Yüksek Öğretim Kurumu. (1997). Üniversite öğrencileri aile gelirleri, eğitim harcamaları, mali yardım ve iş beklentileri araştırması. Erişim adresi: http://www.yok.gov.tr/egitim/raporlar/ailegel.html.

Yüksek Öğretim Kurumu. (2004). Türk yükseköğretiminin bugünkü durumu. Erişim adresi: http://www.yok.gov.tr/egitim/raporlar/raporlar.htm. 


\section{EXTENDED ABSTRACT}

\section{Introduction}

Education has a cost. A state or an individual allocates a certain part of the resource to education by giving up some other areas that should spend or sacrificing from these areas. Naturally, this resource allocation means a cost in terms of separator. In theoretical and experimental studies on the relationship between education and economy, it was concluded that education provides economic gain for both the individual and the society, increases the efficiency of the society, contributes to the future welfare level of the country and has an economic value for short. Therefore, it can easily be said that the expenditures on education are not wasted expenditures. The main purpose of this research is to estimate the rates of return to higher education.

\section{Method}

Survey method was used in the research. The data gathered from people graduated from the certain branches of higher education and has worked as wage earners at private sector in Istanbul. The data related to costs were obtained from the findings of the research had been done previously by YOK, the data on earnings were gotten from wage earners at private sector by a questionnaire developed by the researcher. The social and private rate of returns were estimated using short-cut method. Social and private productivity of the investments in higher education were tested by benefit-cost ratio.

\section{Results}

795 people graduated from relevant university fields and paid in the private sector were reached. 340 of them are women 455 of them are men. In general, the social rate of return in university investments was $8.9 \%$ and the private return was $16.6 \%$. In the cost-benefit ratios, a figure of 11.93 and 15.17 in private terms was reached. There was no significant difference in return rates by gender. The rate of returns are $16.3 \%$ for women and $16.9 \%$ for men.

A $8.9 \%$ social rate of return means that the government earn $8.9 \%$ a year after an investment in higher education, which is significantly higher. This result does not reflect the social benefits of university education. If social benefits could be included in this rate, it would be said that the social rate of return would be higher than that of physical capital investments or government bonds. It can be said that this investment is profitable when considered individually.

\section{Conclusion}

Considering the results of studies conducted in Turkey appears to be similar to the results found in this study. Gürer (1981) only calculated the private rates of return to higher education and found it as $13 \%$. Tunç (1998) calculated the private rates of return in higher education as $14 \%$ for the public sector and $28 \%$ for the private sector. Tansel (1994) found that as the level of education increases, the returns to education increase, especially the returns provided by women are higher than that of men for all levels of education.

As it is understood from the results, the social rates of return in all fields are very close to each other. These findings are similar to many results in Psacharopoulos (1993) calculating the rate of return at different areas in different countries. For example, the social rate of return for the social sciences in Canada is 8.8\% in 1985; 9\% in 1967 for the economics $11.7 \%$ for engineering; $4.5 \%$ for architecture. In the field of social sciences in Great Britain, these rates were $13 \%$ for $1967 ; 11 \%$ for $1971 ; 6 \%$ for the 1971 in the field of engineering and technology.

These findings are generally consistent with the results uncovered in the world and Turkey. For example, in the calculation by Blaug (1972), it was revealed that the private rates of return in the USA are higher than the social rates of return. Cohn and Geske (1990) also stated that in all studies conducted in the USA, the private rates of return vary between $10 \%$ and $15 \%$, while social returns are lower than this. In a study conducted by Psacharopoulos and Patrinos (2004) for many countries, the social rate of return to higher education in countries in the lower income group (with a per capita income of $\$ 755$ ) is $11.2 \%$; in middle income countries (where per capita income is up to $\$ 9265$ ), this rate is $11.3 \% ; 9.5 \%$ in high income countries. According to this research, the global social rate of return is $10.8 \%$. In the same research, private rate of returns to higher 
education is $12.4 \%$ and $19 \%$ worlwide.

As for the cost-benefit ratio, this ratio is known to be an important indicator of the external efficiency of university education. A ratio of 11.93 indicates that the benefits obtained by the society essentially exceed the costs of university education, in which case it can be said that the investment in this level of education is profitable for the state. The same is true for individuals. 